\title{
Suppression of the Eag1 potassium channel sensitizes glioblastoma cells to injury caused by temozolomide
}

\author{
THAIS TORQUATO SALES ${ }^{1 *}$, FERNANDO FRANCISCO BORGES RESENDE ${ }^{1 *}$, \\ NATÁLIA LEMOS CHAVES ${ }^{2}$, SIMONEIDE SOUZA TITZE-DE-ALMEIDA ${ }^{1}$, SÔNIA NAIR BÁO ${ }^{2}$, \\ MARCELLA LEMOS BRETTAS ${ }^{2,3}$ and RICARDO TITZE-DE-ALMEIDA ${ }^{1}$
}

${ }^{1}$ Technology for Gene Therapy Laboratory, Central Institute of Sciences, Faculty of Agronomy and Veterinary Medicine; ${ }^{2}$ Department of Cellular Biology, Institute of Biological Sciences; ${ }^{3}$ Planaltina Campus, University of Brasília, Brasília DF 70910-900, Brazil

Received September 25, 2015; Accepted June 16, 2016

DOI: $10.3892 / \mathrm{ol} .2016 .4992$

\begin{abstract}
Glioblastoma multiforme (GBM) is the most aggressive type of human primary brain tumor. The standard treatment protocol includes radiotherapy in combination with temozolomide (TMZ). Despite advances in GBM treatment, the survival time of patients diagnosed with glioma is 14.5 months. Regarding tumor biology, various types of cancer cell overexpress the ether à go-go 1 (Eag1) potassium channel. Therefore, the present study examined the role of Eag1 in the cell damage caused by TMZ on the U87MG glioblastoma cell line. Eag1 was inhibited using a channel blocker (astemizole) or silenced by a short-hairpin RNA expression vector (pKv10.1-3). pKv10.1-3 (0.2 $\mu \mathrm{g}$ ) improved the Eag1 silencing caused by $250 \mu \mathrm{M}$ TMZ, as determined by reverse transcription-quantitative polymerase chain reaction and immunocytochemistry. Additionally, inhibiting Eag1 with the vector or astemizole $(5 \mu \mathrm{M})$ reduced glioblastoma cell viability and sensitized cells to TMZ. Cell viability decreased by $63 \%$ for pKv10.1-3 + TMZ compared with 34\% for TMZ alone, and by $77 \%$ for astemizole + TMZ compared with $46 \%$ for TMZ alone, as determined by MTT assay. In addition, both the vector and astemizole increased the apoptosis rate of glioblastoma cells triggered by TMZ, as determined by an Annexin V apoptosis assay. Collectively, the current data reveal that Eag1 has a role in the damage caused to glioblastoma by TMZ.
\end{abstract}

Correspondence to: Dr Ricardo Titze-De-Almeida, Technology for Gene Therapy Laboratory, Central Institute of Sciences, Faculty of Agronomy and Veterinary Medicine, University of Brasília, 128 Darcy Ribeiro Academic Campus, Brasília DF 70910-900, Brazil

E-mail: ricardo.titze@pq.cnpq.br

${ }^{*}$ Contributed equally

Key words: ether à go-go 1, Kv10.1, U87MG glioblastoma multiforme cell line, RNA interference, temozolomide, astemizole, short hairpin RNA, gene therapy
Furthermore, suppression of this channel can improve the action of TMZ on U87MG glioblastoma cells. Thus, silencing Eag1 is a promising strategy to improve GBM treatment and merits additional studies in animal models of glioma.

\section{Introduction}

Glioblastoma multiforme (GBM) is an astrocytoma of malignancy grade 4 , thus, it is a glioma with the highest degree of histological abnormality $(1,2)$. This malignant glioma grows rapidly due to the loss of signals that inhibit cell cycle progression and the increased signaling mediated by growth factors $(3,4)$. The standard treatment consists of maximum surgical resection, radiotherapy and chemotherapy with temozolomide (TMZ), which is the first-line therapeutic agent for GBM $(3,5)$. TMZ is a lipophilic substance with a low molecular weight (194.15 g/mol), meaning it is well absorbed by the oral route and crosses the blood-brain barrier to reach the target site (6). This alkylating agent generates cytotoxic DNA lesions in tumor cells that results in cell cycle arrest and apoptosis. Chemotherapy with TMZ has shown clinical benefits in increasing mean survival time and improving patient quality of life (7). However, survival time is only extended by 2.5 months in comparison with radiation therapy alone. Indeed, $\sim 70 \%$ of patients with GBM present no benefit following TMZ treatment, highlighting the urgent need for novel anticancer approaches (8).

Voltage-gated potassium channels have gained increased attention in research regarding tumor biology and therapeutics (9). Ether à go-go 1 (Eag1) is a potassium channel that is overexpressed in various types of tumor, which plays a role in tumorigenesis $(10,11)$. Both low-grade and high-grade human gliomas express Eag1 (12). To the best of our knowledge, no previous studies have evaluated whether TMZ effects Eag1 expression in glioblastoma cells. However, TMZ is known to lead to an increase in $\mathrm{p} 53$ protein expression, which accounts for its antitumor effects (13). In addition, technologies that restore wild-type p53 function improve the effects of TMZ on glioma cells (14). p53 protein negatively regulates Eag1 $(15,16)$; therefore, we hypothesize that TMZ, at least indirectly, may reduce Eag1 expression, amplifying the drug effects on glioma cells. 
Eag1 is a definitive oncological target. Previous studies have utilized different approaches to reveal that decreasing Eag1 activity can undermine tumor progression (17). First, Eag1 blockers imipramine and astemizole were shown to reduce tumor cell growth (18-20). Monoclonal antibodies against Eag1 also had the ability to control tumor development, and proved as effective as the standard agent, cyclophosphamide, in a mouse model of breast cancer (21). Finally, RNA interference (RNAi), the 'state of art' tool for gene therapy, has also been applied to determine the role of Eag1 in cancer. RNAi-based agents for cancer therapy are already in clinical testing and will become approved treatments in the coming years (22). Small-interfering RNAs (siRNAs) designed to silence Eag1 may reduce the growth of different cancer cells in culture (23). Our previous studies developed a plasmid vector able to express short hairpin RNA (shRNA) that targets Eag1 mRNA, termed pKv10.1-3. This expression vector also reduced the viability of glioblastoma cells and increased the cell damage caused by interferon $-\gamma(\operatorname{IFN}-\gamma)$, a therapeutic agent for brain tumors $(24,25)$.

In the present study, the effect of TMZ on Eag1 expression was examined in U87MG glioblastoma cells. In addition, the study evaluated whether silencing Eag1 with shRNA would increase the cell damage caused by TMZ, the first-line therapeutic agent for glioblastoma.

\section{Materials and methods}

Cell culture. U87MG human glioblastoma cells were purchased from the Bank of Cells of Rio de Janeiro (Rio de Janeiro, Brazil). Cells were maintained with Dulbecco's modified Eagle medium (DMEM)/F12 [supplemented with $10 \%$ (v/v) heat-inactivated fetal calf serum, 1\% GlutaMAX and 1\% penicillin/streptomycin solution, all obtained from Invitrogen (Thermo Fisher Scientific, Inc., Waltham, MA, USA)] in $25-\mathrm{cm}^{3}$ culture flasks at $37^{\circ} \mathrm{C}$ in a $5 \% \mathrm{CO}_{2}$ atmosphere.

Drug treatment. TMZ (Orion Corporation, Espoo, Finland) and astemizole (Sigma-Aldrich, Madrid, Spain) were dissolved in dimethyl sulfoxide (DMSO; Sigma-Aldrich) and stored at $-20^{\circ} \mathrm{C}$. The final concentration of DMSO in culture medium did not exceed $0.01 \%$; therefore, it had no influence on cell viability, according to preliminary experiments (data not shown). Details of each experimental procedure are presented in the figure legends and schematic representations.

Cell viability measurement by MTT assay. Cell viability was determined by the MTT method. Briefly, glioma cells were grown in 96 well plates in triplicates $\left(10^{4}\right.$ cells/well $)$ at $37^{\circ} \mathrm{C}$ in a $5 \% \mathrm{CO}_{2}$ atmosphere. ATZ blocker $(5 \mu \mathrm{M})$ was added 30 minutes prior to TMZ $(250 \mu \mathrm{M})$ treatment for $24 \mathrm{~h}$. Subsequently, culture medium was exchanged and incubated for an additional $48 \mathrm{~h}$. Mock control group were cells without ATZ blocker and TMZ treatment. After each experimental treatment, the cells were incubated with $15 \mu \mathrm{l}$ MTT $(5 \mathrm{mg} / \mathrm{ml}$ in DMEM) for $4 \mathrm{~h}$ at $37^{\circ} \mathrm{C}$. Subsequently, the medium was removed and $150 \mu 1 \mathrm{DMSO}$ was added to each well to dissolve formazan crystals. A microplate reader (SpectraMax M2 Microplate Reader; Molecular Devices, Sunnyvale, CA, USA) calibrated to read absorbance at $595 \mathrm{~nm}$ was used to quantify the formazan product. All experiments were performed in triplicate. The number of independent assays performed are indicated in the figure legends.

Cell transfection method. The present study used a previously described shRNA expression vector targeting the Eag1 mRNA sequence (5'-GTCCACTTGGTCCATGTCCAG-3'), termed pKv10.1-3, and the negative control pScramble (24). Following the experimental treatment, Lipofectamine 2000 and Opti-MEM (Invitrogen; Thermo Fisher Scientific, Inc.) were used to transfect pKv10.1-3 and pScramble, according to the manufacturer's instructions. Both fragments were cloned into the pSilencer 3.1-H1 vector. Briefly, glioblastoma cells were grown for $24 \mathrm{~h}$ and then transfected in Opti-MEM for $6 \mathrm{~h}$ at $37^{\circ} \mathrm{C}$ in a $5 \% \mathrm{CO} 2$ atmosphere. Subsequently, the medium was exchanged for DMEM/F12 (Thermo Fisher Scientific, Inc.), following by addition of $\mathrm{TMZ}$ at $250 \mu \mathrm{M}$ or $500 \mu \mathrm{M}$. Glioblastoma cells without any treatment comprised the mock control group.

RNA isolation, cDNA synthesis and reverse transcription-quantitative polymerase chain reaction ( $R T$-qPCR). Monolayer cell cultures were grown in 6-well plates with a density of $6 \times 10^{5}$ cells per well. Total RNA was extracted using an RNeasy Mini kit (Qiagen, Hilden, Germany), according to the manufacturer's instructions, and quantified by fluorometry (Qubit 2.0 firmware 3.11; Thermo Fisher Scientific, Inc.). Purity was considered acceptable for RNA/protein ratios $>1.8$. RNA integrity was analyzed by agarose gel electrophoresis using ethidium bromide (Invitrogen $^{\mathrm{TM}}$; Thermo Fisher Scientific, Inc.). $1 \mathrm{~Kb}$ DNA Ladder (Thermo Fisher Scientific, Inc.) was used as a molecular weight marker. Absence of DNA contamination following RNA extraction was checked by fluorometry and qPCR with negative RT controls. cDNA synthesis was performed from $2.5 \mathrm{ng}$ total RNA using oligo(dT) primers (SuperScript First-Strand Synthesis System for RT-PCR; Thermo Fisher Scientific, Inc.), according to the manufacturer's protocol. The qPCR reaction was conducted in a QuantStudio $12 \mathrm{~K}$ Flex Real-Time PCR System (Applied Biosystems ${ }^{\mathrm{TM}}$; Thermo Fisher Scientific, Inc.). The forward and reverse primers for Eag1 were 5'-TTGGAGATGTGTTCTGGAAGGAA-3' and 5'-AGGGCATCCCGCTTGATC-3', respectively (26). Poly(A) polymerase alpha (PAPOLA) was used as the reference gene with the following primers: Forward, 5'-GCTACGAAGACC AGTCCATTG-3' and reverse, 5'-TGTTGGTCACAGATG CTGCT-3' (24,27). PAPOLA was selected as the reference gene based on a previous study that evaluated the stability of various endogenous reference genes in tumor cells (27). That study also presented four genes that had a high gene expression stability score; therefore, the present study analyzed these four genes: TATA-binding protein (forward 5'-GCT GGCCCATAGTGATCTTT-3' and reverse 5'-CTTCACACG CCAAGAAACAGT-3'); GC-rich promoter binding protein (forward 5'-TCACTTGAGGCAGAACACAGA-3' and reverse 5'-AGCACATGTTTCATCATTTTCAC-3'); Cullin 1 (forward 5'-GCGAGGTCCTCACTCAGC-3' and reverse 5'-TTCTTT CTCAATtAGAATGTCAATGC-3'); and PAPOLA. Among them, PAPOLA showed the lowest rate of $\mathrm{Cq}$ value variation (qPCR) in glioma cells with Eag1 silencing compared with 
controls $(\sim 2 \%)$, an experimental condition that also reduces cell viability. Amplification products were detected via intercalation of the fluorescent dye Fast SYBR Green Master Mix (Applied Biosystems ${ }^{\mathrm{TM}}$ ). Briefly, $10 \mu \mathrm{l}$ reaction mix contained 5.0 $\mu \mathrm{l}$ Fast SYBR Green Master mix, $2.0 \mu \mathrm{l}$ cDNA, and $0.4 \mu \mathrm{l}$ each forward and reverse primer $(10 \mathrm{pmol} / \mu \mathrm{l})$. The PCR cycling conditions included an initial denaturation step at $95^{\circ} \mathrm{C}$ for $5 \mathrm{~min}$, followed by 40 cycles of amplification $\left(95^{\circ} \mathrm{C}\right.$ for $1 \mathrm{~min}, 60^{\circ} \mathrm{C}$ for $1 \mathrm{~min}$ ). Each sample was analyzed in triplicate, and the assay included non-template negative RT controls. The relative quantification method $(\Delta \Delta \mathrm{Cq})$ was used to express the RNAi effects on Eag1 mRNA expression (28). Samples without RNA were used as RT negative controls.

Flow cytometry apoptosis assay. An Alexa Fluor 488 Annexin V/Dead Cell Apoptosis kit (Invitrogen; Thermo Fisher Scientific, Inc.) was used for apoptosis analysis. Samples were prepared according to the manufacturer's protocol with minor modifications. In brief, $1 \times 10^{5}$ cells were plated in 12 -well plates. Following treatment, cells were washed with phosphate-buffer saline (PBS) and resuspended in a solution containing $100 \mu \mathrm{l}$ binding buffer, $5 \mu \mathrm{l}$ Annexin V-fluorescein isothiocyanate (FITC) and $10 \mu 1$ propidium iodide (PI) for $10 \mathrm{~min}$ in the dark at room temperature. Next, $400 \mu \mathrm{l}$ binding buffer was added to the cells and 10,000 events were acquired for each sample. PI fluorescence was analyzed in a flow cytometer (FACSVerse ${ }^{\mathrm{TM}}$; BD Biosciences, Franklin Lakes, NJ, USA) at $617 \mathrm{~nm}$ and the Annexin V-FITC fluorescence was detected at $488 \mathrm{~nm}$. Following acquisition, data were analyzed using FlowJo version 7.6.5 software (Tree Star Inc., Ashland, OR, USA).

Immunocytochemistry and image analysis. For immunocytochemical detection of Eag1, U87MG glioblastoma cells $\left(1 \times 10^{5}\right)$ were first cultured on coverslips in 24 -well plates. Then, cells were fixed with $4 \%$ paraformaldehyde for $15 \mathrm{~min}$ and permeabilized with $10 \%$ Triton X-100 in PBS for $10 \mathrm{~min}$. Nonspecific binding was blocked with $5 \%$ horse serum $\left(\mathrm{Gibco}^{\mathrm{TM}}\right.$; Thermo Fisher Scientific, Inc.) in PBS for $1 \mathrm{~h}$. The previously described Eag1 green fluorescence-labeled primary mouse monoclonal antibody, anti-Eag1.62.mAb (kindly provided by Prof. Walter Stuhmer, Max Planck Institute for Biophysical Chemistry, Göttingen, Germany) (21), was used at a concentration of $1 \mu \mathrm{g} / \mathrm{ml}$ (1:500 dilution) and incubated overnight at $4^{\circ} \mathrm{C}$. The cells were incubated with Alexa Fluor 488-labeled anti-mouse IgG antibody (catalog no., A-11001; 1:2,000 dilution; Molecular Probes; Thermo Fisher Scientific, Inc.) for $1 \mathrm{~h}$ in the dark at room temperature. The cell nuclei were labeled with Hoechst 33342 dye (Sigma-Aldrich) for $5 \mathrm{~min}$ at room temperature. To evaluate the morphology of cytoskeleton, a commercial kit for phalloidin detection (Alexa Fluor 532 Phalloidin; 200 U/ml; Molecular Probes; Thermo Fisher Scientific, Inc.) was used, according to the manufacturer's protocol. The coverslips were mounted and observed with a confocal microscope (TCS SP5; Leica Microsystems, Wetzlar, Germany).

The following formula was used to measure the corrected total cell fluorescence (CTCF) for Eag1: CTCF = integrated density - (area of selected cell x mean fluorescence of background readings). Cell morphology was visualized using a binary (mask-like) image of phalloidin detection and cell nuclei labeled with Hoechst 33342 dye (Sigma-Aldrich). Image analysis was conducted using Image J version 1.47 software (National Institutes of Health, Bethesda, MD, USA). Each experimental condition was performed in triplicate in three independent experiments.

Statistical analysis. All data were analyzed using SPSS software (version 20.0; IBM SPSS, Armonk, NY, USA) and expressed as mean \pm standard error of the mean. One-way analysis of variance followed by Tukey's test was used to determine differences between groups. Differences between pairs of experimental groups were analyzed by Student's t-test. $\mathrm{P}<0.05$ was used to indicate a statistically significant difference.

\section{Results}

TMZ affects the viability of U87MG glioblastoma cells. Initially, a dose-response curve was constructed to examine the cell damage of TMZ on glioblastoma cells by performing an MTT assay. The mock control group, without any treatment, was taken as $100 \%$ viability. TMZ caused a decrease in cell viability in all time periods examined (24, 48 and $72 \mathrm{~h}$ ). As shown in Fig. 1A, the intensity of cell damage varied according to the TMZ concentration and the duration of treatment. At $125 \mu \mathrm{M}$, TMZ caused a slight but stable decrease in cell viability compared with the mock group (100\%) to 91, 87 and $89 \%$ after 24, 48 and 72 h, respectively (Fig. 1A). However, cells exposed to $250 \mu \mathrm{M} \mathrm{TMZ}$ exhibited a significant time-dependent change in viability, from $84 \%$ at $24 \mathrm{~h}$ to $54 \%$ at $72 \mathrm{~h}(\mathrm{P}=0.001)$ and $75 \%$ at $48 \mathrm{~h}$ to $54 \%$ at $72 \mathrm{~h}(\mathrm{P}=0.003)$ (Fig. 1A). At the highest concentration evaluated $(500 \mu \mathrm{M})$ TMZ also caused a time-dependent effect. The viability of glioblastoma cells significantly varied between 59 and $13 \%$ between the 24 and $72 \mathrm{~h}$ time-points (Fig. 1A; $\mathrm{P}=0.001$ ).

Thus, at $72 \mathrm{~h}$, glioblastoma cells presented a more linear response to the increasing doses of TMZ (Fig. 1A), with $250 \mu \mathrm{M}$ TMZ decreasing cell viability to a value close to $50 \%$. Therefore, treatment with $250 \mu \mathrm{M}$ TMZ for $72 \mathrm{~h}$ was selected for all subsequent analyses of the role of Eag1 on the effects of TMZ.

Effects of TMZ and pKv10.1-3 on glioblastoma cell viability and Eag1 expression. Initially, Eag1 mRNA expression was determined in TMZ-treated glioblastoma cells by performing RT-qPCR. Treatment with TMZ $(250 \mu \mathrm{M})$ for $72 \mathrm{~h}$ tended to decrease Eag1 mRNA expression (0.78-fold reduction; $\mathrm{P}=0.129$; Fig. 1B). In addition, the shRNA expression vector, pKv10.1-3 (0.2 $\mu \mathrm{g})$, was able to knock down Eag1 mRNA expression. Transfected cells presented a 0.57 -fold decrease in Eag1 expression compared with the pScramble $(0.2 \mu \mathrm{g})$ negative control group, according to $2^{-\Delta \Delta \mathrm{Cq}}$ values $(\mathrm{P}=0.043$; Fig. 1C). Finally, the effect of TMZ on Eag1 expression was determined in cells pre-transfected with pKv10.1-3. The vector significantly enhanced the downregulation of Eag1 expression caused by TMZ on glioblastoma cells at $72 \mathrm{~h}$. Eag1 mRNA content was reduced from 0.78 -fold, for $250 \mu \mathrm{M}$ TMZ alone to 0.31-fold for $250 \mu \mathrm{M}$ TMZ plus pKv10.1-3 $(\mathrm{P}=0.020$; Fig. 1D). 
A

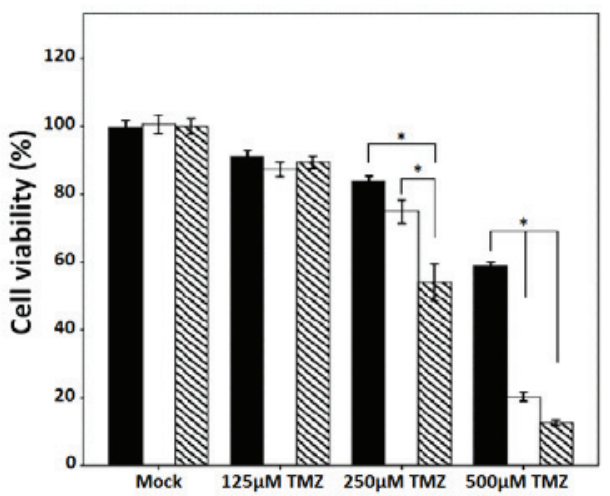

C

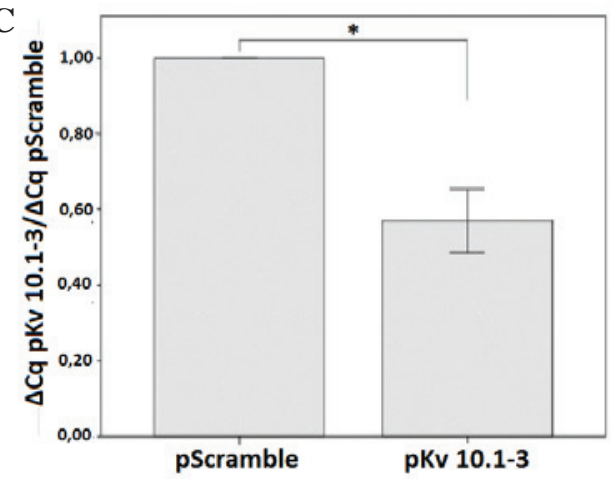

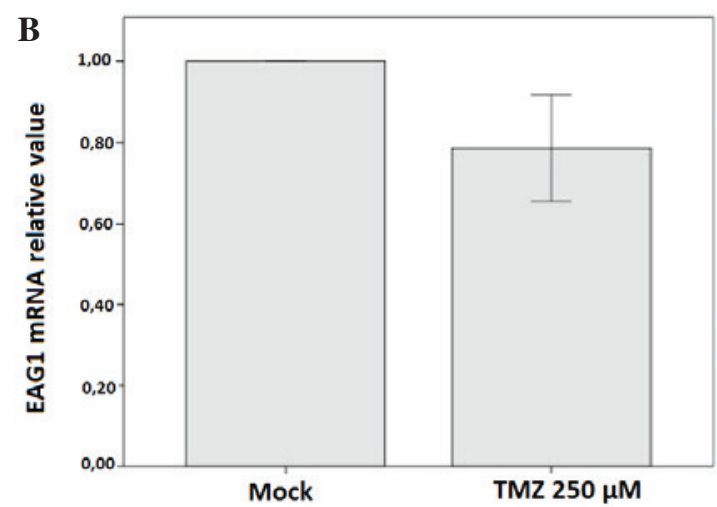

D

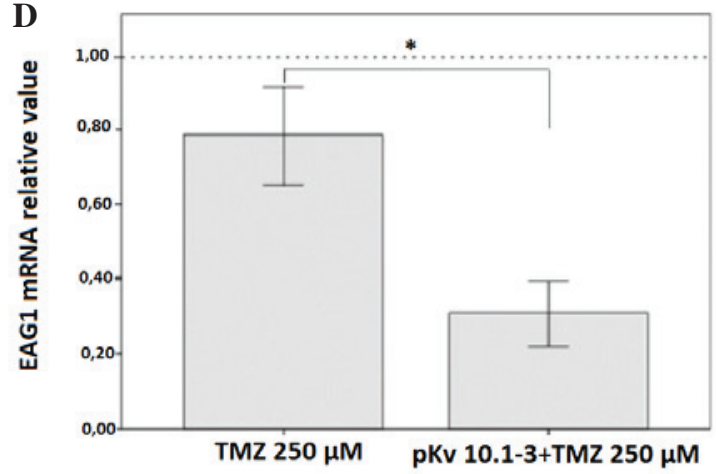

E
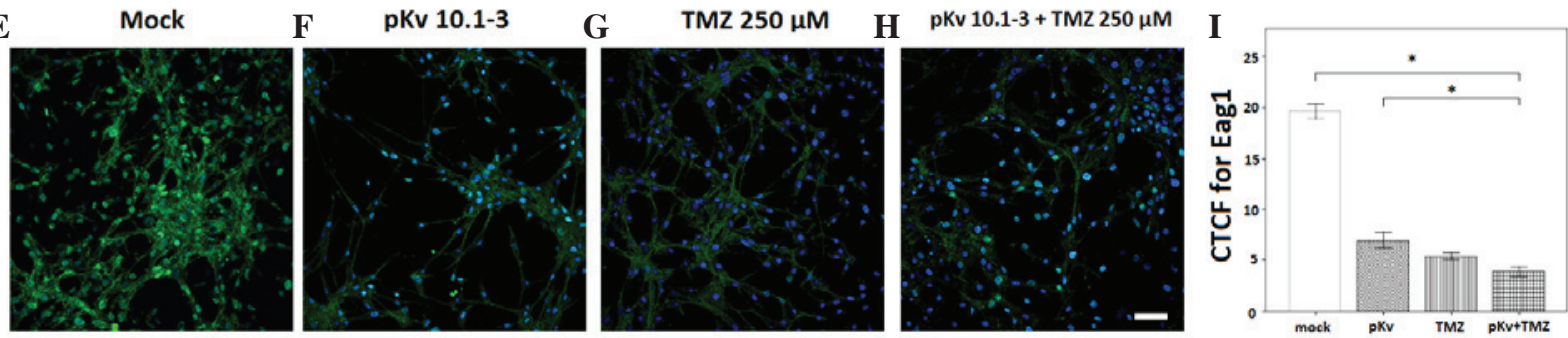

Figure 1. Effects of TMZ and pKv10.1-3 on U87MG cell viability and Eag1 mRNA expression. (A) Cell viability in each TMZ-treated group (125, 250 or $500 \mu \mathrm{M}$ ) was expressed in comparison with the mock control values at 24, 48 and $72 \mathrm{~h}$, as determined by MTT assay. Experimental groups were analyzed in triplicate in eight independent assays. The results are represented as a percentage of the mock control group value. (B) Eag1 mRNA expression in glioma cells treated with $250 \mu \mathrm{M} \mathrm{TMZ}$ per $72 \mathrm{~h}$, as revealed by reverse transcription-quantitative polymerase chain reaction. (C) Effects of pKv10.1-3 (0.2 $\mu \mathrm{g}$ ) on Eag1 mRNA expression compared with a control vector (pScramble). (D) pKv10.1-3 amplified the effect of $250 \mu \mathrm{M}$ TMZ on Eag1 mRNA expression. Data were normalized to the reference gene poly(A) polymerase alpha and compared using the $2^{-\Delta \Delta C q}$ method $(n=3)$. (E-H) Eag1 immunocytochemistry in U87MG cells. Representative confocal microscopy images showing the expression of Eag1 in the (E) mock control group, and the reduced cell filament following treatment with (F) pKv10.1-3, (G) $250 \mu \mathrm{M}$ TMZ or (H) pKv10.1-3 and $250 \mu \mathrm{M}$ TMZ. Scale bar, $20 \mu \mathrm{m}$. (I) CTCF for Eag1. Eag1 intensity was significantly decreased in all treated groups in comparison with the mock. Eag1 intensity was significantly lower in the cell group treated with pKv10.1-3 and 250 $\mu \mathrm{M}$ TMZ in comparison with pKv10.1-3 alone. " $\mathrm{P}<0.05$. Experimental groups were analyzed in triplicate in three independent experiments. All results are expressed as the mean \pm standard error of the mean. CTCF, corrected total cell fluorescence; TMZ, temozolomide; pKv, pKv10.1-3.

Eag1 expression in U87MG cells was also examined by immunocytochemistry (Fig. 1E-H). Eag1 was detected using anti-Eag1.62.mAb labeled with green fluorescence and nuclei were counterstained with Hoechst 33342 (blue) prior to examination by confocal microscopy. Merged squares show the combined images of both Hoechst staining and Eag1 immunodetection (Fig. 1E-H). Eag1 was highly expressed in human U87MG glioblastoma cells (CTCF, 19.65 \pm 0.76 ; Fig. 1E and I) while TMZ and the pKv10.1-3 vector decreased this expression of Eag1 (Fig. 1F-H). Treatment with pKv10.1-3, $250 \mu \mathrm{M}$ TMZ alone or $250 \mu \mathrm{M} \mathrm{TMZ}$ and pKv10.1-3 significantly reduced the CTCF values to $6.97 \pm 0.79,5.37 \pm 0.37$ and $3.86 \pm 0.49$, respectively, compared with the mock control ( $\mathrm{P}=0.001$; Fig. 1I). Eag1 CTCF values was significantly lower in the cell group treated with pKv10.1 3 and $250 \mu \mathrm{M}$ TMZ in comparison with pKv10.1 3 alone ( $\mathrm{P}=0.049$; Fig. 1I).

Astemizole and $p$ Kv10.1-3 reduce the viability of glioblastoma cells. The role of Eag1 on the viability of glioblastoma cells was examined using astemizole, a potassium channel blocker, and pKv10.1-3, a plasmid that silences Eag1. Astemizole caused a dose-dependent effect on the viability of glioblastoma cells treated with this drug for $72 \mathrm{~h}$, as determined by MTT assay (Fig. $2 \mathrm{~A}-\mathrm{C}$ ). At $24 \mathrm{~h}$, cells treated with $2.5,5$ or $10 \mu \mathrm{M}$ astemizole exhibited significant reductions in cell viability of 23 , 57 and $85 \%$, respectively, compared with $0 \mu \mathrm{M}$ astemizole $(\mathrm{P}=0.001$; Fig. $2 \mathrm{~A})$. At the same concentrations, $48 \mathrm{~h}$ of treatment with the drug also caused a dose-response effect, with 
A

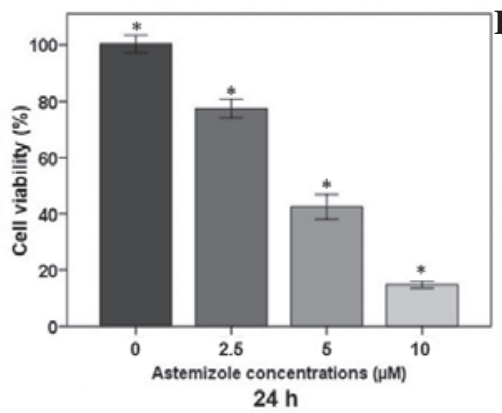

D

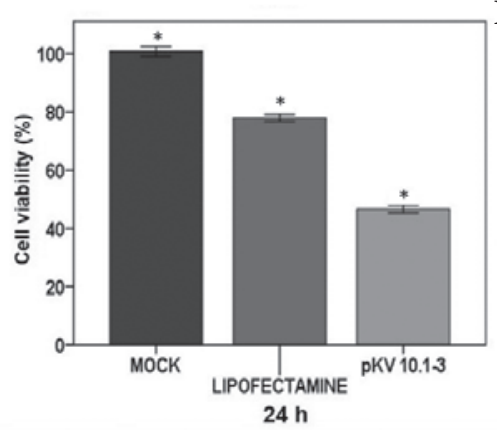

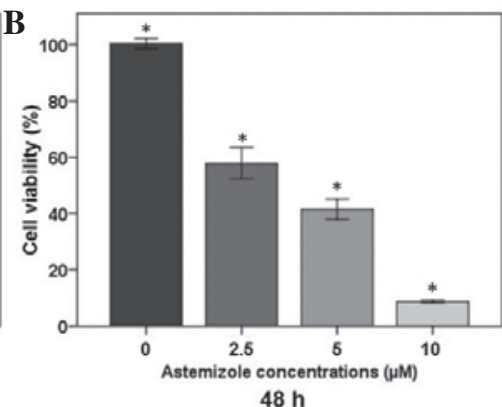

$48 \mathrm{~h}$

E

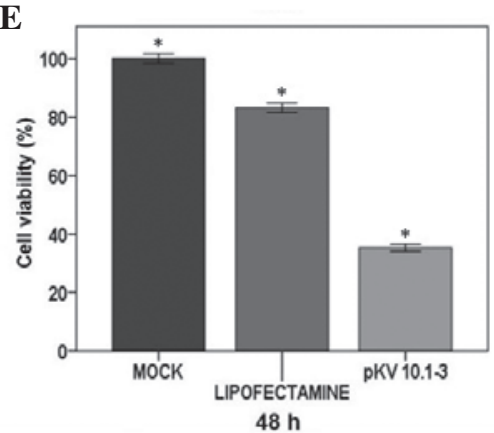

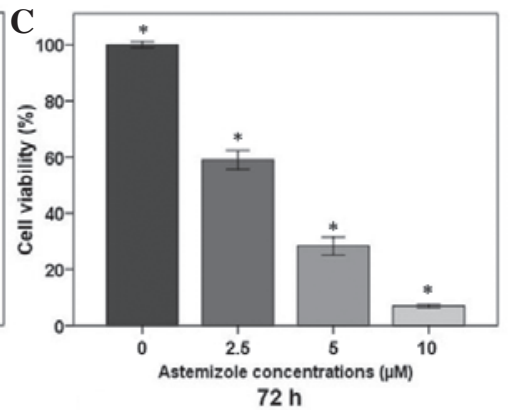

F

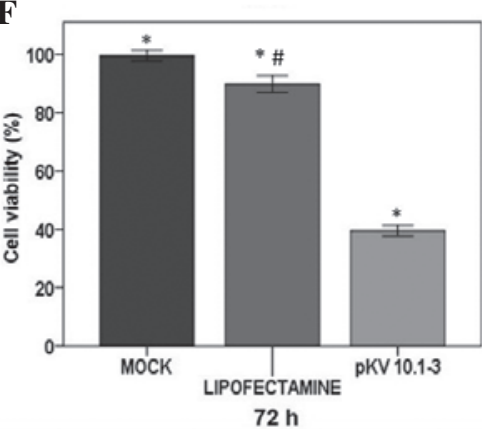

Figure 2. Effects of astemizole (ATZ) and pKv10.1-3 (0.2 $\mu \mathrm{g})$ on U87MG cell viability. (A-C) Effects of different concentrations of ATZ (2.5, 5 and $10 \mu \mathrm{M})$ on cell viability following incubation for 24,48 and 72 h. ${ }^{*} \mathrm{P}<0.05,0$ vs. 2.5 vs. 5 vs. $10 \mu \mathrm{M}$ astemizole. (D-F) Effects of pKv10.1-3 on cell viability at 24,48 and $72 \mathrm{~h}$. Cell viability was determined by MTT assay. ${ }^{*} \mathrm{P}<0.05$, mock vs. lipofectamine vs. pKv10.1-3; ${ }^{\text {P }}<0.05$, mock vs. lipofectamine. All experimental groups were analyzed in triplicate in eight independent assays. The results are represented by a percentage of the mock control group value and are expressed as the mean \pm standard error of the mean.

cell viability decreasing by 42 at $2.5 \mu \mathrm{M}$ up to $93 \%$ at $10 \mu \mathrm{M}$, compared with $0 \mu \mathrm{M}(\mathrm{P}=0.001$; Fig. $2 \mathrm{~B})$. Furthermore, at $72 \mathrm{~h}$, astemizole also reduced the viability of glioma cells by 41,72 and $93 \%$ at doses of 2.5, 5 and $10 \mu \mathrm{M}$, compared with $0 \mu \mathrm{M}$ ( $\mathrm{P}=0.001$; Fig. 2C).

RNAi of Eag1 also affected glioblastoma cell viability. Cells transfected with pKv10.1-3 $(0.2 \mu \mathrm{g})$ showed a stable decrease in viability between 24 and $72 \mathrm{~h}$, as observed by MTT assay. Values of cell viability decreased to 47,35 and $40 \%$ at 24, 48 and $72 \mathrm{~h}$, respectively, after transfection, compared with mock control cells ( $\mathrm{P}=0.001$; Fig. 2D-F). Lipofectamine also caused a decrease in glioblastoma cell viability compared with the mock control that was more intense at $24 \mathrm{~h}(22 \%)$ than at $72 \mathrm{~h} \mathrm{(10 \% ).} \mathrm{Taken} \mathrm{together,} \mathrm{the} \mathrm{results} \mathrm{of} \mathrm{astemizole} \mathrm{and}$ pKv10.1-3 MTT assays confirm a role for Eag1 in preserving glioblastoma cell viability.

Suppression of Eagl by astemizole or pKv10.1-3 sensitizes cells to TMZ. The present study explored the effects of Eag1 potassium channel suppression on the injury caused to glioma cells by TMZ. Cell preparations were treated with TMZ following Eag1 suppression, which varied according to each experimental method. Eag1 blockade with astemizole required 30 min incubation, whereas $6 \mathrm{~h}$ was required for pKv10.1-3 transfection. Experimental groups pretreated with the Eag1 channel blocker astemizole or pKv10.1-3 exhibited a stronger response to TMZ, as examined by MTT assay. Cells incubated with astemizole $(5 \mu \mathrm{M})$ for 30 min followed by $250 \mu \mathrm{M}$ TMZ (Fig. 3A) exhibited a 77\% decrease in cell viability compared with the mock control, a value significantly higher than in groups treated with astemizole $(58 \%)$ or TMZ alone $(46 \%$; $\mathrm{P}=0.001$; Fig. 3A).
Furthermore, glioblastoma cells with silenced Eag1 expression using pKv10.1-3 exhibited a greater reduction in cell viability following the addition of TMZ (Fig. 3B). In the TMZ $(250 \mu \mathrm{M})$ plus pKv10.1-3 $(0.2 \mu \mathrm{g})$ group, cell viability decreased by $77 \%$ compared with the mock control $(\mathrm{P}=0.001)$. This effect was significantly higher in comparison with that found in the group treated with TMZ alone $(48 \% ; \mathrm{P}=0.004)$. Groups treated with $500 \mu \mathrm{M}$ TMZ plus pKv10.1-3 also exhibited a greater decrease in cell viability compared with the TMZ only group. Thus, the vector was able to enhance the effects of TMZ on glioblastoma cells at drug doses of 250 and $500 \mu \mathrm{M}$, indicating a dose-response effect.

Apoptosis of GBM cells determined by flow cytometry. The role of Eag1 suppression on the rate of apoptosis was also examined in glioblastoma cells treated with TMZ. Flow cytometry analysis employing an Annexin V-FITC/PI double staining assay was performed. As shown in Fig. 4A-G, early apoptosis (Annexin V+/PI-) and later stage apoptosis (Annexin V+/PI+) are represented in quadrants Q4 and Q2, respectively. The mock control group corresponds to untreated cells. Suppression of Eag1 increased the induction of apoptosis (Q4 and Q2) caused by TMZ (Fig.4H). For example, treating with TMZ and blocking Eag1 with astemizole significantly increased the glioblastoma cell apoptosis rate induced by TMZ alone by 4.7 -fold, from 17 to $82 \%$ ( $\mathrm{P}=0.001$; Fig. $4 \mathrm{~B}$ vs. $\mathrm{D}$ and $\mathrm{H}$ ). In addition, treating with $\mathrm{TMZ}$ and silencing Eag1 with pKv10.1-3 increased the rate of apoptosis triggered by TMZ alone by 3.6 -fold (17 vs. 63\%; P=0.011; Fig. 4B vs. $\mathrm{G}$ and $\mathrm{H}$ ).

Cell groups subjected to Eag1 suppression and TMZ treatment also showed changes in cell morphology, as revealed by confocal microscopy (Fig. 4I-L). The cell filaments in 
A
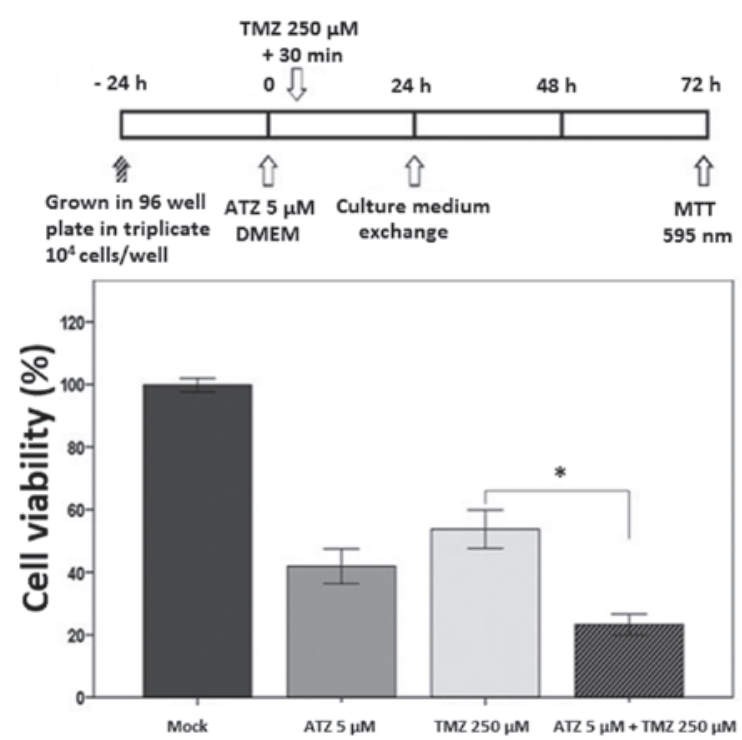

B

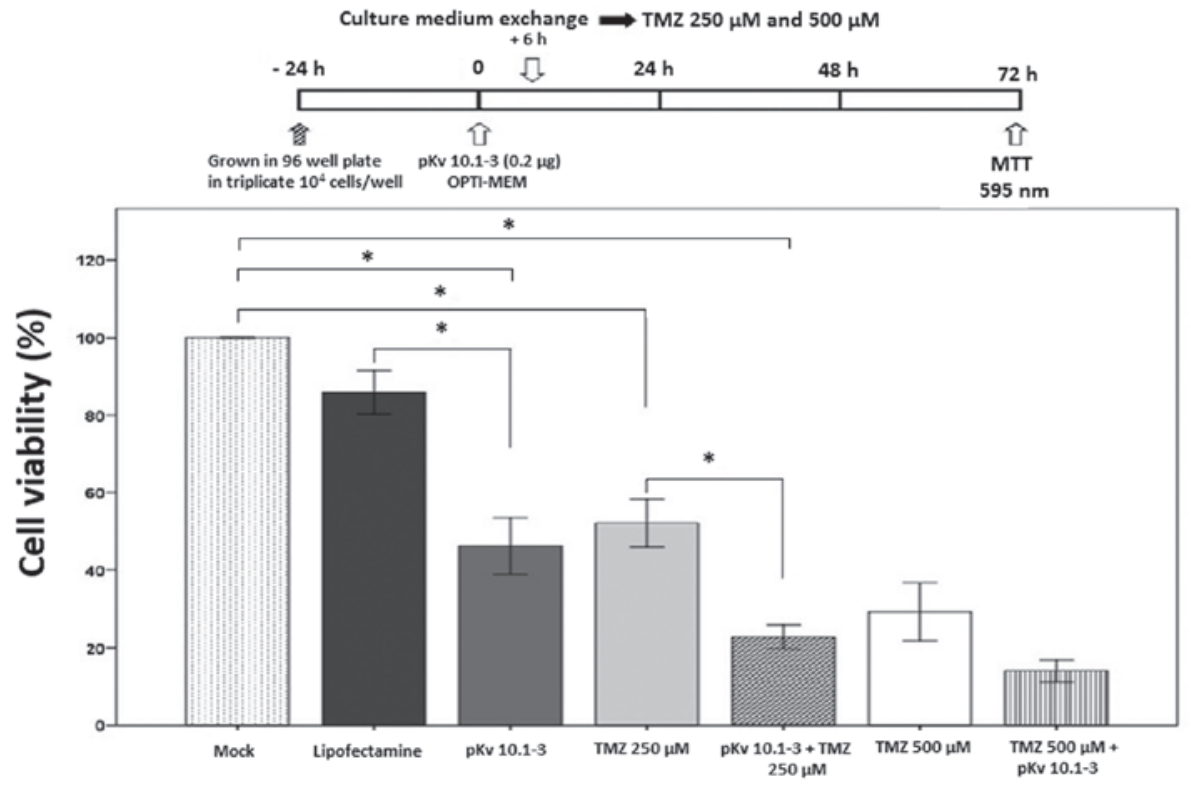

Figure 3. Effects caused by ATZ or pKv10.1-3, in association with TMZ, on U87MG cell viability. A schematic representation of the experimental procedure is shown at the top of each figure. (A) Viability of glioma cells under pharmacological blockade of Eag1 with ATZ, in association with TMZ. (B) Viability of glioma cells following pKv10.1-3 transfection, in combination with TMZ. Cell viability was determined by MTT assay. Experimental groups were analyzed in triplicate in eight independent assays. Data are presented as mean \pm standard error of the mean. ${ }^{*} \mathrm{P}<0.05$. ATZ, astemizole; DMEM, Dulbecco's modified Eagle medium; TMZ, temozolomide.

the pKv10.1-3 plus $250 \mu \mathrm{M}$ TMZ treatment group were relatively thin and less dense compared with the mock controls (Fig. 4I-L, red arrows). The mock group (Fig. 4I) and those that received pKv10.1-3 (Fig. 4J) or $250 \mu \mathrm{M}$ TMZ (Fig. 4K) alone showed a more stable morphology and survival rate, compared with the group treated with pKv10.1-3 plus $250 \mu \mathrm{M}$ TMZ (Fig. 4L). Furthermore, glioblastoma cells treated with pKv10.1 3 plus $250 \mu \mathrm{M}$ TMZ showed lower adherence with round and floating shapes, in comparison with TMZ alone, as determined by visual inspection.

\section{Discussion}

Ion channels have a critical role in tumorigenesis (29). They regulate the flux of ions across the plasma membrane, which influences cell cycle, growth and apoptosis (30). Thus, deregulated activity or expression of ion channels will favor the loss of normal control of cell division, a classic hallmark of cancer (31). Previous studies revealed that Eag1 potassium channels have a role in cell growth, neoplastic behavior and malignancy $(10,17)$. Numerous tumor types display deregulated Eag1 function, including breast cancer cells (20), tumors of head and neck (32), colon $(33,34)$, esophagus (35), cervix (36), and leukemia (37). Gliomas also overexpress Eag1, irrespective of their malignancy grade (12). The present study confirmed that U87MG glioblastoma cells in culture exhibit high expression levels of Eag1 (Fig. 1E).

The aforementioned result confirmed a role for Eag1 in tumorigenesis, highlighting Eag1 as a promising target for anticancer therapy. However, as Eag1 is involved in 


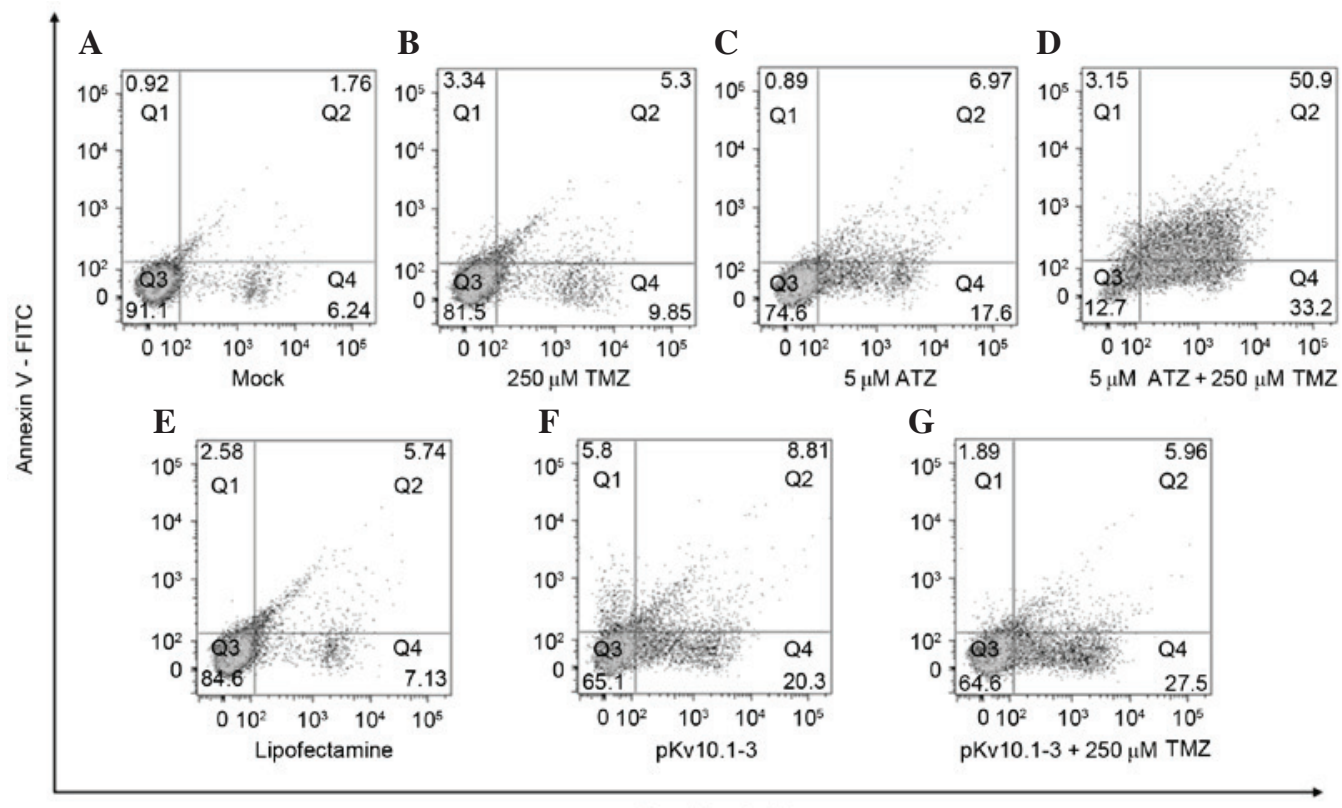

Propidium iodide
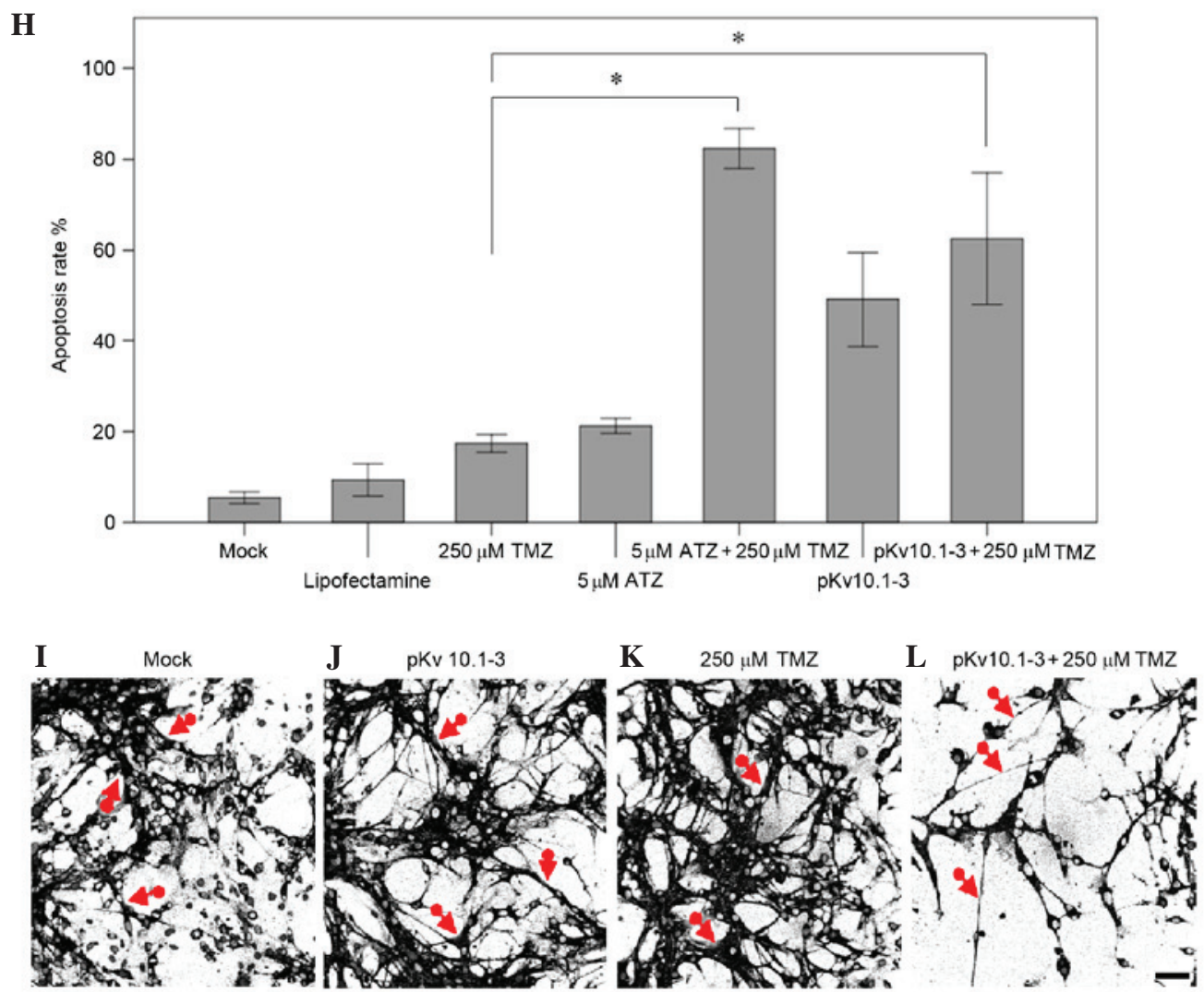

Figure 4. Induction of apoptosis by Eag1 suppression in U87MG glioblastoma cells exposed to TMZ. (A-G) Experimental groups were analyzed after $72 \mathrm{~h}$ by Annexin V/propidium iodide (PI) assay, according to the manufacturer's protocol. Representative scatter plots are shown, indicating the distribution of Annexin V and PI-stained cells. The x-axis indicates PI fluorescence detected at $617 \mathrm{~nm}$ and the $\mathrm{y}$-axis indicates Annexin V-fluorescein isothiocyanate fluorescence detected at $488 \mathrm{~nm}$. Q3 indicate live cells, Q1 indicate necrotic cells, Q2 indicate late apoptotic cells and Q4 indicate early apoptotic cells. (H) Mean of sum of early and late apoptosis in U87MG cells. Results are expressed as a percentage of the total cell number and are presented as mean \pm standard error of the mean. Assays were performed in triplicate of three independent experiments. "P<0.05. (I-L) Representative images acquired by confocal microscope. Binary images were obtained by phalloidin detection in U87MG monolayer cell culture and reveal morphological changes caused by different treatments. Red arrows indicate differences in cell filaments between the group treated with pKv10.1-3 and $250 \mu \mathrm{M} \mathrm{TMZ}$, and the other groups. Scale bar, $20 \mu \mathrm{m}$. Q1-4, quadrant 1-4; TMZ, temozolomide.

electrophysiology, inhibiting channel function may cause adverse effects. In a previous study, an Eag1 knock-out mouse was developed and characterized (38). The animals showed no changes in embryogenesis, brain development or electrical properties of cerebellar Purkinge cells; only mild behavioral changes occurred. Animals that lack an active channel also 
showed no marked changes in physiology, thus, Eag1 appears to be a safe and a promising target for cancer treatment. In fact, studies with monoclonal antibodies, siRNAs, astemizole and imipramine have confirmed that Eag1 inhibition can control cancer development $(18,21,23,39)$. Expression of Eag1 was increased in the brain tumors of patients with shorter overall survival (40). Patients with brain metastasis exhibiting low Eag1 expression and receiving drugs that block Eag1 (tricyclic antidepressants) presented a longer overall survival. These data strongly suggest that Eag1 plays a role in the growth of human brain tumors, revealing this channel as a potential oncologic target.

Astemizole is an antihistamine that also blocks the Eag1 channel. The drug has shown activity against different cancer types, including hepatocellular carcinoma, breast tumors and cervical cancer cells (41-43). The current results corroborated the aforementioned findings in glioblastoma cells, reinforcing the role of Eag1 in cancer cell growth. Astemizole caused a dose-dependent decrease in glioblastoma cell viability following 24, 48 and $72 \mathrm{~h}$ of treatment. The potential use of astemizole in cancer treatment, however, is hindered by its side effects (39). Astemizole may cause ventricular arrhythmia, a rare but potentially fatal toxic effect $(44,45)$. For brain tumors, a second pharmacological property of astemizole would also undermine its efficacy: Its inability to penetrate the blood-brain barrier. Although this pharmacokinetic property is valuable for antihistamines in order to avoid sedation, it is undesirable for drugs that must reach injured brain tissues, as occurs for infiltrating gliomas (46). Thus, the blood-brain tumor barrier represents an obstacle for antiglioma chemotherapy. In the core area of glioblastomas this barrier is leaky, however, it remains unchanged in large parts, blocking the access of anticancer drugs to tumor tissues (47). Thus, a novel therapeutic strategy to inhibit Eag1 is urgently required.

In a previous study, synthetic siRNAs showed the ability to silence Eag1 expression in various types of cancer cells (23). Eag1-targeted siRNAs decreased Eag1 mRNA and protein expression, which resulted in decreased growth in the majority of cell types investigated. Among the four siRNAs evaluated, Kv10.1-3 caused the greatest silencing effect on Eag1, targeting nucleotides 1793-1813 of Eag1 mRNA (http://www.ncbi.nlm.nih.gov/nuccore; NM_172362). However, glioblastoma cells were not examined in this previous study. Therefore, the present study employed the same Eag1 target sequence, which was cloned in an shRNA expression vector termed pKv10.1-3. Our previous study reported that glioblastoma cells transfected with pKv10.1-3 were less viable than untreated controls cells. Indeed, this Eag1 silencing vector also intensified IFN- $\gamma$ damage of glioma cells (24). The present study revealed that $\mathrm{pKv} 10.1-3$ sensitized glioblastoma cells to TMZ, the first-choice drug for the treatment of GBM. It was observed that Eag1 has a role in the cell damage caused by TMZ on glioblastoma cells. First, Eag1 is highly expressed in glioblastoma cells (Fig. 1E). Second, pKv10.1-3 in association with TMZ increased the silencing effect on Eag1 mRNA caused by TMZ alone (0.31- vs. 0.78 -fold reduction; Fig. 1D). Third, the effect displayed by pKv10.1-3 on glioblastoma cell viability at 24, 48 and $72 \mathrm{~h}$ was also observed for astemizole, an Eag1 channel blocker, on a dose-dependent scale (Fig. 2). Fourth, astemizole and pKv10.1-3 treatment both sensitized cells to TMZ injury, decreasing glioblastoma cell viability (77\% for astemizole plus TMZ vs. 46\% for TMZ alone, Fig. 3A; $63 \%$ for pKv10.1-3 plus TMZ vs. $34 \%$ for TMZ alone, Fig. 3B). Fifth, these treatments also caused changes in glioblastoma cell morphology and caused poor adherence in culture flasks. Finally, both astemizole and pKv10.1-3 significantly increased the rate of apoptosis caused by TMZ, as determined by flow cytometry (Fig. 4A-G).

The use of RNAi for Eag1 silencing has previously been reported in other cancer cell lines. A viral vector expressing shRNA to Eag1 reduced tumor growth and angiogenesis of osteosarcoma (48), and siRNAs to Eag1 sensitized ovarian cancer cells to cisplatin (49). To the best of our knowledge, no previous study has examined whether Eag1 gene silencing is able to sensitize glioblastoma cells to TMZ.

In conclusion, the present study revealed that suppression of Eag1 improves the action of TMZ on glioblastoma cells. In addition to highlighting a role for Eag1 in TMZ injury, the current findings also indicate a possible application for Eag1 silencing as an anticancer treatment strategy. Future preclinical studies should analyze pKv10.1-3 in animal models of glioma to confirm if Eag1 is a target for RNAi-based gene therapy.

\section{Acknowledgements}

The present study received financial support from the following Brazilian agencies: Financiadora de Estudos e Projetos (grant no. 2013/05179); Coordenação de Aperfeiçoamento de Pessoal de Nível Superior (Programa Nacional de Pós-doutorado; grant no. 3731-37/2010); Conselho Nacional de Desenvolvimento Científico e Tecnológico (grant no. 467467/2014-5); Fundação de Apoio à Pesquisa do Distrito Federal (grant no. 2010/00302-9). The study has been previously published on the University of Brasília website as the doctoral thesis of Mr. Fernando Francisco Borges Resende at http://repositorio.unb.br/bitstream/10482/20136/1/2016_ FernandoFranciscoBorgesResende_Parcial.pdf.

\section{References}

1. Maher EA, Furnari FB, Bachoo RM, Rowitch DH, Louis DN, Cavenee WK and DePinho RA: Malignant glioma: Genetics and biology of a grave matter. Genes Dev 15: 1311-1333, 2001

2. Lassman AB: Molecular biology of gliomas. Curr Neurol Neurosci Rep 4: 228-233, 2004.

3. Wen PY and Kesari S: Malignant gliomas in adults. N Engl J Med 359: 492-507, 2008.

4. Gladson CL, Prayson RA and Liu WM: The pathobiology of glioma tumors. Annu Rev Pathol 5: 33-50, 2010.

5. Furnari FB, Fenton T, Bachoo RM, Mukasa A, Stommel JM, Stegh A, Hahn WC, Ligon KL, Louis DN, Brennan C, et al: Malignant astrocytic glioma: Genetics, biology, and paths to treatment. Genes Dev 21: 2683-2710, 2007.

6. Nagasawa DT, Chow F, Yew A, Kim W, Cremer N and Yang I: Temozolomide and other potential agents for the treatment of glioblastoma multiforme. Neurosurg Clin N Am 23: 307-322, 2012.

7. Omuro A and DeAngelis LM: Glioblastoma and other malignant gliomas: A clinical review. JAMA 310: 1842-1850, 2013.

8. Chamberlain MC: Temozolomide: Therapeutic limitations in the treatment of adult high-grade gliomas. Expert Rev Neurother 10: 1537-1544, 2010

9. Pardo LA and Stümer W: The roles of $\mathrm{K}(+)$ channels in cancer. Nat Rev Cancer 14: 39-48, 2014.

10. Pardo LA, del Camino D, Sánchez A, Alves F, Brüggemann A, Beckh S and Stühmer W: Oncogenic potential of EAG K(+) channels. EMBO J 18: 5540-5547, 1999. 
11. Hemmerlein B, Weseloh RM, Mello de Queiroz F, Knötgen H, Sánchez A, Rubio ME, Martin S, Schliephacke T, Jenke M, Heinz-Joachim-Radzun, et al: Overexpression of Eagl potassium channels in clinical tumours. Mol Cancer 5: 41, 2006.

12. Patt S, Preussat K, Beetz C, Kraft R, Schrey M, Kalff R, Schönherr K and Heinemann SH: Expression of ether à go-go potassium channels in human gliomas. Neurosci Lett 368: 249-253. 2004

13. Hermisson M, Klumpp A, Wick W, Wischhusen J, Nagel G, Roos W, Kaina B and Weller M: O6-methylguanine DNA methyltransferase and p53 status predict temozolomide sensitivity in human malignant glioma cells. J Neurochem 96: 766-776, 2006.

14. Kim SS, Rait A, Kim E, Pirollo KF, Nishida M, Farkas N, Dagata JA and Chang EH: A nanoparticle carrying the p53 gene targets tumors including cancer stem cells, sensitizes glioblastoma to chemotherapy and improves survival. ACS Nano 8: 5494-5514, 2014

15. Lin H, Li Z, Chen C, Luo X, Xiao J, Dong D, Lu Y, Yang B and Wang Z: Transcriptional and post-transcriptional mechanisms for oncogenic overexpression of ether à go-go K+ channel. PLoS One 6: e20362, 2011.

16. Essmann $\mathrm{F}$ and Schulze-Osthoff $\mathrm{K}$ : Translational approaches targeting the p53 pathway for anticancer therapy. Br J Pharmacol 165: 328-344, 2012

17. Pardo LA and Stühmer W: EAG1: An emerging oncological target. Cancer Res 68: 1611-1613, 2008.

18. Gavrilova-Ruch O, Schönherr K, Gessner G, Schönherr R, Klapperstück T, Wohlrab W and Heinemann SH: Effects of imipramine on ion channels and proliferation of IGR1 melanoma cells. J Membr Biol 188: 137-149, 2002.

19. García-Ferreiro RE, Kerschensteiner D, Major F, Monje F, Stühmer W and Pardo LA: Mechanism of block of hEag1 K+ channels by imipramine and astemizole. J Gen Physiol 124: 301-317, 2004

20. Roy J, Vantol B, Cowley EA, Blay J and Linsdell P: Pharmacological separation of hEAG and hERG K+ channel function in the human mammary carcinoma cell line MCF-7. Oncol Rep 19: 1511-1516, 2008.

21. Gómez-Varela D, Zwick-Wallasch E, Knötgen H, Sánchez A Hettmann T, Ossipov D, Weseloh R, Contreras-Jurado C, Rothe M, Stühmer W and Pardo LA: Monoclonal antibody blockade of the human Eag1 potassium channel function exerts antitumor activity. Cancer Res 67: 7343-7349, 2007.

22. Burnett JC and Rossi JJ: RNA-based therapeutic: Current progress and future prospects. Chem Biol 19: 60-71, 2012.

23. Weber C, Mello de Queiroz F, Downie BR, Suckow A, Stühmer W and Pardo LA: Silencing the activity and proliferative properties of the human EagI potassium channel by RNA interference. J Biol Chem 281: 13030-13037, 2006

24. Cunha LC, Del Bel E, Pardo L, Stühmer W and Titze-DE-Almeida R: RNA interference with EAG1 enhances interferon gamma injury to glioma cells in vitro. Anticancer Res 33: 865-870, 2013.

25. Kane A and Yang I: Interferon-gamma in brain tumor immunotherapy. Neurosurg Clin N Am 21: 77-86, 2010.

26. Mareschi K, Novara M, Rustichelli D, Ferrero I, Guido D, Carbone E, Medico E, Madon E, Vercelli A and Fagioli F: Neural differentiation of human mesenchymal stem cells: Evidence for expression of neural markers and each $\mathrm{K}+$ channel type. Exp Hematol 34: 1563-1572, 2006.

27. Kwon MJ, Oh E, Lee S, Roh MR, Kim SE, Lee Y, Choi YL, In YH, Park T, Koh SS and Shin YK: Identification of novel reference genes using multiplatform expression data and their validation for quantitative gene expression analysis. PLoS One 4: e6162, 2009.

28. Livak KJ and Schmittgen TD: Analysis of relative gene expression data using real-time quantitative PCR and the 2(-Delta Delta C(T)) method. Methods 25: 402-408. 2001.

29. Kunzelmann K: Ion channels and cancer. J Membr Biol 205: $159-173,2005$

30. Kondratskyi A, Kondratska K, Skryma R and Prevarskaya N: Ion channels in the regulation of apoptosis. Biochim Biophys Acta 1848: 2532-2546, 2015.

31. Lang F, Föller M, Lang KS, Lang PA, Ritter M, Gulbins E, Vereninov A and Huber SM: Ion channels in cell proliferation and apoptotic cell death. J Membr Biol 205: 147-157, 2005.
32. Menéndez ST, Villaronga MA, Rodrigo JP, Alvarez-Teijeiro S, García-Carracedo D, Urdinguio RG, Fraga MF, Pardo LA, Viloria CG, Suárez C and García-Pedrero JM: Frequent aberrant expression of the human ether à go-go (hEAG1) potassium channel in head and neck cancer: Pathobiological mechanisms and clinical implications. J Mol Med (Berl) 90: 1173-1184, 2012.

33. Ding XW, Yan JJ, An P, Lü P and Luo HS: Aberrant expression of ether à go-go potassium channel in colorectal cancer patients and cell lines. World J Gastroenterol 13: 1257-1261, 2007.

34. Ousingsawat J, Spitzner M, Puntheeranurak S, Terracciano L, Tornillo L, Bubendorf L, Kunzelmann K and Schreiber R: Expression of voltage-gated potassium channels in human and mouse colonic carcinoma. Clin Cancer Res 13: 824-831, 2007.

35. Ding XW, Luo HS, Jin X, Yan JJ and Ai YW: Aberrant expression of Eag1 potassium channels in gastric cancer patients and cell lines. Med Oncol 24: 345-350, 2007.

36. Ortiz CS, Montante-Montes D, Saqui-Salces M, Hinojosa LM, Gamboa-Dominguez A, Hernández-Gallegos E, Martínez-Benítez B, Del Rosario Solís-Pancoatl M, Garcia-Villa E, Ramírez A, et al: Eag1 potassium channels as markers of cervical dysplasia. Oncol Rep 26: 1377-1383, 2011.

37. Agarwal JR, Griesinger F, Stühmer W and Pardo LA: The potassium channel Ether à go-go is a novel prognostic factor with functional relevance in acute myeloid leukemia. Mol Cancer 9: $18,2010$.

38. Ufartes R, Schneider T, Mortensen LS, de Juan Romero C, Hentrich K, Knoetgen H, Beilinson V, Moebius W, Tarabykin V, Alves F, et al: Behavioural and functional characterization of Kv10.1 (Eag1) knockout mice. Hum Mol Genet 22: 2247-2262, 2013.

39. García-Quiroz J and Camacho J: Astemizole: An old anti-histamine as a new promising anti-cancer drug. Anticancer Agents Med Chem 11: 307-314, 2011.

40. Martínez R, Stühmer W, Martin S, Schell J, Reichmann A, Rohde V and Pardo L: Analysis of the expression of Kv10.1 potassium channel in patients with brain metastases and glioblastoma multiforme: impact on survival. BMC Cancer 15: 839, 2015.

41. de Guadalupe Chávez-López M, Pérez-Carreón JI, Zuñiga-García V, Díaz-Chávez J, Herrera LA, Caro-Sánchez CH, Acuña-Macías I, Gariglio P, Hernández-Gallegos E, Chiliquinga AJ and Camacho J: Astemizole-based anticancer therapy for hepatocellular carcinoma (HCC), and Eag1 channels as potential early-stage markers of HCC. Tumour Biol 36: 6149-6158, 2015

42. García-Quiroz J, García-Becerra R, Santos-Martínez N, Barrera D, Ordaz-Rosado D, Avila E, Halhali A, Villanueva O, Ibarra-Sánchez MJ, Esparza-López J, et al: In vivo dual targeting of the oncogenic Ether-à-go-go-1 potassium channel by calcitriol and astemizole results in enhanced antineoplastic effects in breast tumors. BMC Cancer 14: 745, 2014.

43. de Guadalupe Chávez-López M, Hernández-Gallegos E, Vázquez-Sánchez AY, Gariglio P and Camacho J: Antiproliferative and proapoptotic effects of astemizole on cervical cancer cells. Int J Gynecol Cancer 24: 824-828, 2014.

44. de Abajo FJ and Rodríguez LA: Risk of ventricular arrhythmias associated with nonsedating antihistamine drugs. Br J Clin Pharmacol 47: 307-313, 1999.

45. Oppenheimer JJ and Casale TB: Next generation antihistamines: Therapeutic rationale, accomplishments and advances. Expert Opin Investig Drugs 11: 807-817, 2002.

46. González MA and Estes KS: Pharmacokinetic overview of oral second-generation $\mathrm{H} 1$ antihistamines. Int J Clin Pharmacol Ther 36: 292-300, 1998

47. van Tellingen O, Yetkin-Arik B, de Gooijer MC, Wesseling P, Wurdinger T and de Vries HE: Overcoming the blood-brain tumor barrier for effective glioblastoma treatment. Drug Resist Updat 19: 1-12, 2015.

48. Wu J, Wu X, Zhong D, Zhai W, Ding Z and Zhou Y: Short Hairpin RNA (shRNA) Ether à go-go 1 (Eag1) inhibition of human osteosarcoma angiogenesis via VEGF/PI3K/AKT signaling. Int J Mol Sci 13: 12573-12583, 2012.

49. Hui C, Lan Z, Yue-Li L, Li-Lin H and Li-Lin H: Knockdown of Eag1 expression by RNA interference increases chemosensitivity to cisplatin in ovarian cancer cells. Reprod Sci 22: 1618-1626, 2015. 